(Paper No. 2985.)

"The Mushkaf-Bolan Railway, Baluchistan, India."

By J JMES RAMSAY, M. Inst. C.E.

The Bolan.

The Bolan Pass has, from time immemorial, formed part of the great trade-route to Afghanistan from the South. It is more than 60 miles long; and, from 450 feet, at its lower entrance, it rises to a height of 6,000 feet above mean sea-level. At this elevation it opens out into the Pishin Plateau, at a spot bearing the inauspicious but well-deserved name of the Dasht-i-bedowlat "the unhappy plain." Many of the hill-peaks near the top of the pass rise to heights between 8,000 feet and 10,000 feet above the sea.

The entrance to the pass from the plains of Sind, about 4 miles west of Dadur, is through the Kundilani Gorge, which is about 20 miles long. This gorge is'everywhere surrounded by high hills, and contracts from a width of $\frac{1}{2}$ mile at the lower end until, for a short distance, about half-way, it is less than 200 feet wide; while for a length of some 2 miles the width is never greater than 400 feet, with sheer cliffs of hard limestone conglomerate rising 300 feet to 500 feet above the stream. It gradually widens out to about 1,000 feet, where it opens on to the Lalachi Plain, a dreary waterless waste of limestone boulders and shingle some 25 miles long by about 6 miles wide, which is surrounded by bare, solid limestone hills between 2,000 feet and 5,000 feet high, pierced by deep, narrow clefts, through which storm-waters are poured on to the plain.

The Upper Bolan, from Mach to the summit at Kotal Darwaza, is about 16 miles long. The width of the gap at Mach is 1,000 feet, which suddenly increases to about 1 mile, to contract again below Hirok, about half-way, to little more than $\frac{1}{4}$ mile. The dry bed of the Bolan torrent from Mach to Hirok is some 500 feet wide, cut sheer down to a depth of between 50 feet and 100 feet into the shingle beach which occupies the eastern side of the gorge, the limestone-conglomerate hills rising 1,000 feet to 3,000 feet above it. Firok is at the lower end of the Dozan Gorge, and 
for some miles through this gorge the Bolan occupies a deep and particularly tortuous cleft in the solid limestone rocks, never more than 300 feet, and in some places less than 100 feet wide, the cliffs on each side rising sheer 200 feet and 600 feet above the dry torrent-bed, the surrounding hill-tops being often 3,000 feet and 5,000 feet higher.

The Bolan stream gushes from under the Lalachi Plain a short distance above the upper end of the Kundilani Gorge, so that water always flows in the gorge, and tends somewhat to soften its weird desolation. Although the surface of the Lalachi Plain is furrowed with innumerable dry water-channels of varying depths and widths, it is almost without water, inhabitants, or vegetation, and it is strewn with limestone boulders of every size. At Mach there is always water from springs, but this disappears among the shingle and boulders in the torrent-bed a short distance down-stream; while above Mach there is only one spring in the Bolan Gorge, and its waters almost immediately disappear deep into the shingle.

The difficulties of the Bolan Pass were first recognised when the English Army, marching on Kandahar at the commencement of the Afghan war in February 1839, took ten days in going from Dadur to Quetta, and suffered fearful privations from the inclemency of the weather, as well as from scarcity of water and provisions; while the wretched track over the boulders and shingle in the torrent beds lamed both men and cattle.

In the winter of 1857-8 a survey for a line of railway from Sukkur to Dadur, near the entrance to the Bolan Pass, was commenced by engineers of the old Sind-Punjab and Delhi Railway Company. It was carried from Sukkur through Shikarpur for about 50 miles, when it was stopped, as there seemed no chance of the project being carried out. In 1876 the Government of India ordered a reconnaissance to be made of the passes into Baluchistan. It was reported of the Bolan Pass that its winding narrowness, great acclivity, and number and depth of the ravines leading into it for its whole length, presented many difficulties to the construction of a railway through it, which must of necessity be costly; while the flattest gradient it would be possible to obtain in the upper end being 1 in 20 , on curves of 70 feet radii, would cause expensive working, and much time would be needed to seek out a line and construct it to the best advantage. Of the other passes it was reported that, though they presented fewer difficulties than the Bolan, their defiles were frequently narrow and tortuous, and any railway through them would be costly to construct, while leading far distant from the strategic point aimed at. 
After the news of the massacre at Cabul in 1879, the Government of India issued orders to lay a line of rails from Ruk to Sibi, at the entrance to the Nari Pass, about 20 miles east from the Bolan. Orders for the collection of the necessary materials from the reserve stocks of all the railways in India were issued on the 10th September, 1879; the first rail was laid at Ruk on the 1st October, and the last rail into Sibi was laid on the 15th January, 1880; thus the 133 miles of broad-gauge railway were laid in three and a half months, or at an average rate of $1 \frac{1}{4}$ mile per day. ${ }^{1}$ Greater speed would have been made but for the difficulty of feeding and watering three thousand five hundred men and fifteen hundred animals in the middle of a waterless, sandy desert. This line and its extension towards Quetta and Afghanistan were under the direction of Sir Richard Temple, Bart., G.C.S.I., then Governor of Bombay, who, with his engineers, further reconnoitred the Passes; and on their reports the Government of India decided, notwithstanding the extreme reluctance of the Military Authorities, to abandon the old route, via the Bolan, for the littleknown route via the Harnai Valley, because the difficulties on the Harnai route were considered to be far less than those on the Bolan, and military exigencies demanded a line of railway towards Kandahar to be undertaken without delay. This line (known as the Kandahar Railway), of the metre gauge, was commenced at once, and a considerable amount of work was carried out on it, under Colonel James Lindsay, R.E., the Engineer-inChief, before it was ordered by the Home Government to be abandoned in 1881 .

During 1880 the broad-gange line was extended west from Sibi to Pir Chowki, at the mouth of the Bolan Pass, a distance of 19 miles, and was found to be of the greatest service in assisting the transport of troops and stores towards Kandahar. Wooden pile bridges were erected across the Nari and Kumbri rivers, but they were sources of great anxiety, owing to their liability to damage from sudden floods. Both were replaced by permanent bridges, which were completed in 1882, the Nari Bridge having seven spans of girders 100 feet in the clear, and the Kumbri three spans of girders 60 feet in the clear, on well-foundations. Rindli, reputed to be the hottest place in the world, $16 \frac{1}{2}$ miles from Sibi, was afterwards made the terminus, and extensive sidings for military purposes were laid down.

During the summer season the country along the base of these

1 Minutes of Proceedings Inst. C.E., vol. lxi. pp. 274 and 286. 
hills, and in their lower passes, is almost uninhabitable; the hot winds blow with a force and a heat beyond description, with the air as dry, hot, and dust-laden as that of a newly-drawn limekiln; and, until the railway staff went there, only the lizard and the hornet dared be abroad. Long before the great heat sets in the Brahui tribes regularly migrate, with their flocks and herds, to the cooler altitudes of the Quetta Plateau, and never return until the commencement of the cold season.

From Rindli a rough cart-track, through the Bolan to Quetta, was constructed by General Phayre, in command of the Bombay Army, during the advance on Kandahar in 1879-80, and was found of great service in facilitating the passage of troops and military stores through this dreaded locality. It was afterwards handed over to the Royal Engineers of the Military Works Department, who, by their skill in alterations and improvements, carried out at intervals up to a recent date, have converted it into a road fit for wheeled traffic of every description, certain to prove of immense assistance when military operations are again undertaken beyond the frontier. It is metalled and bridged throughout, and, being scarped out along the cliffs well above the reach of the Bolan floods, is not liable to damage, except in a few localities from hill-side slips, which can, however, be speedily repaired. In the Kundilani Gorge there is a short tunnel throug.h a spur of the conglomerate cliffs, and close by is a wrought-iron girder bridge, 200 feet in the clear, completely spanning the chasm.

In 1883 the Government decided to resume the abandoned works in the Harnai Valley as a military road, and the late Colonel Browne, C.S.I., (afterwards Major-General Sir James Browne, K.C.S.I., C.B., R.E.), was appointed Engineer-in-Chief, with a staff of Royal Engineers. Considerable progress was made with the works before it was decided, in 1884, to extend the broadgauge railway from Sibi up the Harnai Valley to the Pishin Plateau, under the name of the Sind-Pishin State Railway. The staff had to be augmented by Civil Engineers, and; platelaying being vigorously proceeded with, the rails (which for considerable distances were laid along the bed of the Nari river) reached a point about 20 miles north from Sibi, when, early in 1885, an abnormal flood, or what was then considered to be such, caused immense and costly damage by wiping out the line for miles; so that, when the Author joined it as Superintending Engineer, the locomotives could only run to about 10 miles from Sibi. A succession of floods during the spring and summer greatly interfered with the works, especially at the numerous large 
bridges over the Nari river; but by April the material trains were regularly worked on the permanent formation to the twentieth mile from Sibi, the temporary line in the river-bed being lifted. Unfortunately all work on this lower length had to be completely closed and the staff dispersed in May, 1885, owing to the outbreak of a terrible cholera epidemic which carried off the native work-people in hundreds, and it was not until the middle of September that work could be resumed.

After the Panjdeh incident, the Government of India determined to have speedier railway communication with Quetta than the SindPishin Railway (Harnai route) promised to afford. It was, therefore, decided to lay a temporary surface broad-gauge line rapidly up the Bolan Pass, the work being entrusted to Colonel James Lindsay, R.E., as Engineer-in-Chief, who commenced operations at Rindli (440 feet above sea-level) in April, 1885. The season proved most unfavourable, and a fearful epidemic of cholera breaking out, which carried off both Europeans and coolies, the work was practically stopped after some 8 miles of rails had been laid. Mr. F. L. O'Callaghan, M. Inst. C.E., C.I.E., succeeded Colonel Lindsay in June, 1885, and, by great exertions and exposure on the part of the staff, the line to Hirok $(4,600$ feet above sealevel), about 50 miles from Rindli, was completed on the 19 th November of the same year. The permanent way was laid in the Bolan torrent-bed, crossing and recrossing the water-channels incessantly on 10-foot span openings formed of crib-piers made from wooden sleepers. Owing to their liability to be underscoured by freshets, the maintenance of these innumerable crib-piers was found to be so troublesome and expensive, that they were soon largely removed, and the permanent way was laid on the shingle, so that trains were safer, even though they were frequently running through swiftly flowing water, 12 or 15 inches above the rails, when crossing the bends of the water-channel in the Kundilani Gorge. The permanent way consisted of 75 -lb. steel rails on cast-iron sleepers (Denham-Olpherts pattern), and 80-1b. and 68-lb. old iron rails, with cast-iron chairs on wooden sleepers. The ruling gradient for the first 35 miles was 1 in $40(2.5$ per cent. $)$, then about 8 miles of 1 in $30(3 \cdot 3$ per cent.), and for about 7 miles the gradient was 1 in 25 ( 4 per cent.), the minimum radius of curves being 800 feet $\left(7^{\circ} 10^{\prime}\right) \cdot{ }^{1}$

During this time the works for a temporary metre-gauge line

2 The angles are those subtended at the centre of curvature by a chord of 100 feet. 
about 9 miles long, through the Upper Bolan, from Hirok to Kolpur (Kotal ${ }^{1}$ Darwaza), 5,900 feet above sea-level, were,actively proceeded with, as well as those for the broad-gauge permanent line from Kolpur (Kotal Darwaza) to Quetta (5,500 feet above sea-level), a length of 25 miles. As soon as the materials could be brought up to Hirok for it, the metre-gauge line was laid in the Bolan torrentbed, following the tortuous windings through the narrow Dozan Gorge. The permanent way used was old broad-gauge doubleheaded iron rails, weighing $80 \mathrm{lbs}$. and $68 \mathrm{lbs}$. per yard, with castiron chairs on broad-gauge wooden sleepers. The ruling gradient was 1 in $23(4.35$ per cent.), the sharpest curve being about 200 feet radius $\left(28^{\circ} 30^{\prime}\right)$, and the line was opened for traffic in March, 1886. It was worked with Fairlie locomotives. The works from Kolpur (Kotal Darwaza) to Quetta were all of a permanent character; the ruling gradient is 1 in 100 ( 1 per cent.), laid with flat-footed steel rails weighing 75 lbs. per yard, on steel transverse trough sleepers to the 5-foot 6-inch gauge; and the line was opened for traffic in Angust, 1886, when Mr. O'Callaghan's connection with it ceased. Extensive arrangements were in use for transhipping materials from the broad to the metre gauge at Hirok, and at Kolpur (Kotal Darwaza) from the metre to the broad gauge.

This Bolan Railway justified its construction by its political effect after the Panjdeh incident, and the assistance it gave towards enabling the Sind-Pishin Railway (Harnai route) to be opened for traffic more than twelve months sooner than it could have been otherwise. Owing to the comparative immunity from damage by floods, enjoyed by the Bolan Railway during the first two years of its existence, the authorities were beguiled into thinking it could be maintained as a permanent means of communication with the Pishin Plateau; and a proposition was made, in 1887, to construct a high-level line from Hirok to Kolpur, with a ruling gradient of 1 in $23(4.35$ per cent.), in place of the metre-gauge line in the bed of the ravine, to give through communication with Quetta on the standard gauge, and do away with the expensive transhipping arrangements in use at Hirok and Kolpur. This was sanctioned by the Government of India, and the opportunity was taken to enquire into the working of the Abt rack system of traction, resulting in some 5 miles of this system of permanent way, and two locomotives, being ordered from Messrs. Rinecker $\&$ Co. In 1888-9 about 1 mile of this was laid, above Hirok, for experimental purposes with the locomotives; but an un-

1 Kotal, meaning the summit of a pass. 
favourable report was the result, and the racks were stacked at Hirok, the locomotives being sent to the workshops.

On this so-called "high-level" line the works in some places were heavy, and there was one short tunnel; but the line was kept at too low levels through the ravine, and economy was carried to the verge of recklessness, by fitting the waterways across the gorges to suit a limited quantity of old metre-gauge materials. It had hardly been passed as fit for traffic, in the summer of 1889 , when heavy rains among the surrounding high hills caused a severe flood down the gorges, which did great damage not only to the "high-level" line, but also to the line laid along the torrent-bed below Hirok, as far as Rindli. About the same time the SindPishin Railway (Harnai route) suffered very great damage from a flood due to still heavier rains in that locality, and railway communication with the Quetta garrison was completely suspended.

At the end of 1889, the Author took charge of the Sind-Pishin and Bolan Railways as Engineer-in-Chief, and reconstruction work was vigorously undertaken. The lower lengths of the Bolan (Quetta Loop it was called officially) were rapidly repaired, and the upper length was strengthened, and some of the waterways lengthened. Late in the summer of 1890 a heavy rainfall among the hills above Hirok caused another and still more destructive flood in the Bolan, which completely wrecked the line in the Dozan Gorge, buried some of the bridges under heaps of shingle, carried away many of the others without leaving a vestige behind, and seriously damaged the masonry piers and abutments of the remainder; while, below Hirok and Mach, and at the Kundilani Gorge, all traces of the line were completely obliterated for miles.

When rain does fall in these arid regions of high, bare, limestone hills, the water acquires high velocity in rushing down the precipitous gorges with which their steep sides are cleft; and, though the volume of water may not be very great, the steep declivities give extraordinary impulse and force to the floods during the short time they last. It was stated, by an eye-witness of the flood of 1890, that the roar from the boulders being trundled along the torrent-bed in the Dozan Gorge was deafening; and, although the water was not more than 1 foot or 2 feet deep, so great was the speed with which the boulders were hurled at obstructions that the cutwaters of the stone piers, at the few bridges left standing, were battered out of shape to heights of more than 10 feet above the torrent-bed. Huge boulders weighing many tons each were, at the same time, carried considerable distances. This flood settled the question of through communication on this so- 
called "high-level" line, and gave the engineers many most useful lessons in mountain engineering.

The great difficulty and expense experienced, during blinding blizzards of both snow and hail, in repairing the Sind-Pishin Railway (Harnai route), and the cost and uncertainty of its upkeep and regular working, strengthened the determination of the Government of India to have another, and, if possible, reliable railway to Quetta; that place being the great military cantonment on the North-West frontier, of immense strategic importance, with its lines of invulnerable fortifications extending for miles on the hill-sides, all constructed and armed in accordance with the latest scientific military principles.

\section{The Mushkaf-Bolan.}

During the construction of the temporary railway in the Bolan Pass, in 1885-86, Mr. F. L. O'Callaghan examined into and reported on the practicability of constructing a permanent railway by this route to the plateau. A preliminary survey was made for a line by way of the Mushkaf Valley with a ruling gradient of 1 in $40(2 \cdot 5$ per cent.) throughout, and the works were estimated to cost Rs.165,00,000. This project was submitted to the Government of India in September 1886, but for various reasons it was not proceeded with.

In November 1890, the detailed surveys for the new railway were entrusted by the Government of India to the Author, in addition to his other duties, with instructions to submit plans and estimates for the provision of a safe line of communication between India and the Baluchistan Plateau, which would be more reliable than the existing lines, out of reach of the Bolan floods throughout, and free from land-slides and similar interruptions to traffic. It was not deemed necessary to further consider the route via the Kundilani Gorge, as that was very intimately known, and had already been reported on; so that the thorough study of the less-known Mushkaf Valley was decided on, for getting the stable line required. The preliminary plans above mentioned were of much assistance to the staff in selecting the line ultimately adopted. It was seen that the Mushkaf river is 200 feet higher than the Bolan, at the point where they are divided from each other by a high though narrow range of limestone hills, 26 miles from Sibi, and this neighbourhood was considered to be the key to the route. The original plans showed a reverse gradient of 
1 in 50 ( 2 per cent.), with very heavy works, for $2 \frac{1}{2}$ miles down into the Bolan Valley (28 miles from Sibi); and, unless this could be flattened to 1 in 100 ( 1 per cent.), or to 1 in 80 ( 1.25 per cent.), at the steepest, either costly and troublesome siding arrangements would have to be made, at both top and bottom, for changing the positions of the engines of all double-engine trains before commencing the descent or ascent, according to the direction in which they might be working, or this route might have to be abandoned. To determine this, a series of careful trial lines were run over this extremely difficult piece of country, and it was eventually found that 1 in 100 (1 per cent.) could be substituted for the 1 in 50 ( 2 per cent.), by facing some additional very heavy works, with an extra tunnel through a spur from the main range, and keeping at higher levels on the hill-slopes along the Bolan Valley. Estimates, amounting to Rs.137,17,565, with completed plans and sections for the construction of the new railway, $56 \frac{3}{4}$ miles of single line of 5 -foot 6 -inch gauge, were submitted to Government in September 1891; and were sanctioned in November, with orders for the works to be commenced at once, the Author being appointed Engineer-in-Chief, and relieved from the charge of the Sind-Pishin (Harnai route) open line; and, there can be no doubt, had the works not been starved for want of funds, this new railway could have been finished in the spring of 1894. The old Bolan Railway was included in this charge, with orders that it was to be so far kept open as to be available for military purposes, if required.

As the Khojak Tunnel through the Kwaja Amran range, between Quetta and Kandahar, had just been completed, the opportunity was seized of securing a large quantity of the tunnelling machinery, and other plant for the Mushkaf-Bolan Railway; so that a good start was made during the working season 1891-92, with the crowds of people flocking to the works from Hazara and Afghanistan generally. At the same time, a line of telegraph was commenced to connect the head office with the different district offices; some changes were made for improving the old Bolan Railway by taking it out of the torrent-bed below Mach on to a new alignment, where, for some 8 miles or 9 miles, it was safe from floods ; and the rails were placed lower in the shingle, at the numerous "dips" crossing the river-channel in the Kundilani Gorge, so that, at these places, trains were running through swiftly flowing water of greater depths than before, with the great advantage that the permanent way was much less liable to damage from ordinary freshets. 
As the Government also determined that all the tunnels and the masonry of all the bridges were to be built for a double line throughout, some alterations in the alignment had to be made, especially in the Upper Bolan, which increased the length of the new railway to 58.75 miles. Revised estimates had therefore to be prepared to include the new works, and were sanctioned, amounting to Rs.2,00,85,470, being at the rate of Rs.3,38,088 per mile.

The Mushkaf Valley is nearly as long as the Bolan, but its drainage-area is much smaller, and its declivity less severe. Though it is, perhaps, even more dreary, weird, and desolate than the Bolan, it is nowhere so wide, nor are its gorges so deep. The width is seldom more than about $\frac{1}{4}$ mile for short distances; and, except near its head-waters, the geological formation is soft sandstone with layers of green and red clays, and occasional patches of limestone boulder conglomerate. There is in the Mushkaf valley lardly any stone fit for bridge-building.

The Mushkaf-Bolan Railway, Figs. 1 and 2, Plate 7, runs for about 5 miles from Sibi ( 433 feet above sea-level) on the old Bolan Railway formation, across the Nari river to the new Nari Bank station, where the new works commence, and, curving to the right, traverses an open sandy plain to the Mushkaf Gorge, 12 miles from Sibi, and 520 feet above sea-level. From here, the country traversed by the new railway may be divided into three well-defined sections, having distinctly different local features. The first 18 miles are cut through very rough country, with numerous high rocky spurs requiring fourteen tunnels, cuttings more than 70 feet deep, and a few embankments 90 feet or 100 feet high. The next 16 miles are over an open waterless country, strewn with boulders of all shapes and sizes, requiring an abnormal number of bridges to pass the storm-waters that occasionally pour down the numerous gorges by which the steep sloping hill-sides are deeply scored, and if checked would simply overwhelm the line with masses of rocks and boulders. The upper 16 miles are in a wild country of high, bare, limestone rocks, where the hills rise to heights of between 6,000 feet and 10,000 feet above sea-level, necessitating the construction of six tunnels, heavy earthworks both in cuttings and embankments, and expensive special bridging across the deep tortuous channels cut by the Bolan torrents.

The railway enters the Mushkaf Gorge, which is only about 400 feet wide, through a tunnel 470 feet long; then passes boldly across a bend of the river on two large bridges, and five tunnels through the numerous saw-toothed soft sandstone spurs, these

[THE INST, C.E. VOL. CXXVIII.] 
heavy works extending over about $1 \frac{1}{2}$ mile. The principal works are shown in the following Table :-

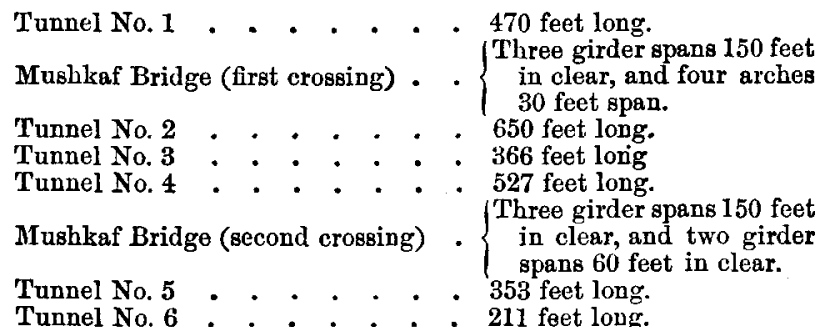

These tunnels are through layers of soft sandstone alternating with bands of indurated clay, most treacherous materials to deal with, as the clay, though extremely hard and troublesome to blast while in situ, becomes very friable when exposed to the air, and falls down in great masses with but little warning. Heavy timbering was necessary throughout, and the enlarging and arching had to proceed simultaneously, with English miners to overlook the native work-people. All are three-quarter lined with brick masonry in Portland-cement mortar. At Ocepur station (982 feet above sealevel), $19 \frac{1}{4}$ miles from Sibi, the railway again crosses the Mushkaf river, in a deep gorge cut down through limestone conglomerate, on a girder bridge of 200 feet clear span; thence, after traversing a number of ravines and passing through two tunnels, the Mushkaf river is crossed for the fourth time, and about 1 mile further on is Panir station, 1,411 feet above sea-level and $26 \frac{1}{4}$ miles from Sibi. The principal works on this length are :-

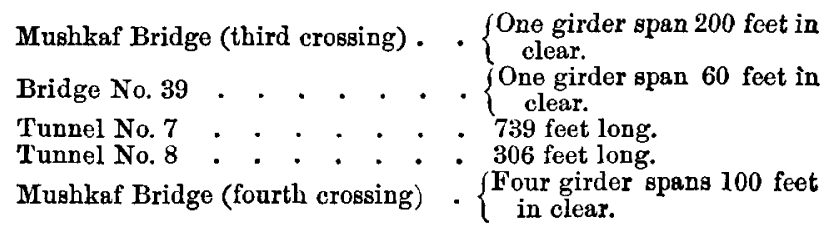

Tunnels Nos. 7 and 8 are through the high cliffs along the left bank of the Mushkaf river, in conglomerate with occasional claybands, and are three-quarter lined with brick masonry. They were excavated for the most part by means of short horizontal adits run in from the cliff faces.

As there is practically no water in the lower Mushkaf Valley, advantage was taken of some springs near Tunnel No. 7 to build a collecting sump, from which water was conveyed by gravity for about 12 miles through 4-inch wrought-iron piping, and was 
distributed to the various works in pipes of smaller diameter, the total fall in the 12 miles being 650 feet. A temporary railway was laid from Nari Bank station to the southern or Sibi end of the Panir Tunnel, for the conveyance of materials by rail to the neighbourhood of the various bridges and tunnels, and proved of the greatest assistance in pushing on the works. Its gradients in the Mushkaf Gorge were stiff, and a short length of 1 in 25 was necessary to avoid expensive works in rising out of the gorge.

About 1 mile beyond Panir station, and 27 miles from Sibi, the longest tunnel on this railway occurs. It passes through Panir Bund, the narrow range of hills dividing the Mushkaf from the Bolan Valley. The Panir Tunnel (1,468 feet above sea-level) was originally proposed to be 3,000 feet long, but, owing to rotten sandstone with red clay being met with at the Sibi end, it has since been lengthened by 218 feet. Work was commenced upon it in November 1892; the headings met in August 1893; the average rate of progress working out to 13 lineal feet per day; and the tunnel was completed in August 1895, native labour only having been employed on its construction. It traverses for the most part nummulitic limestone of varying quality, so that the extent of lining varies accordingly, being in some places three-quarter lined, while in others it is only one-half or quarter lined. The roofs of the tunnels are all lined, as it has been found that the atmosphere and products of combustion from locomotives exercise injuriously disintegrating effects on even the hardest rocks in unlined tunnels, causing pieces to fall from the roofs and sides, thus endangering the safety of trains. This is the only tunnel at which machinedrills, worked by compressed air, were extensively used. The air-compressing plant was erected on the Bolan side of the hill, and while the compressed air was supplied to the Bolan heading, which was the one principally worked, it was also conveyed to the Sibi heading by a separate line of $4 \frac{1}{2}$-inch wrought-iron pipes, about 6,500 feet long, laid over the Panir hill, the summit of which rises 1,000 feet above the tunnel. Both Schram and Climax machine-drills were used. The latter was found more suitable for the hard strata, and its simplicity better fitted it for the native labour, though excellent work was accomplished with the Schram drills in the softer strata. In the widening out, the machine-drills were superseded by hand labour which was found to be cheaper.

These works were connected with the railway system, on the Sibi side, by the temporary railway from the Nari Bank station already mentioned. On the Bolan side a temporary branch, 5 miles long, was laid across the Lalachi Plain from the old Bolan Railway, a 
short distance above the upper end of the Kundilani Gorge, to the foot of the Panir hill, for the conveyance of materials and stores by train. As the tunnel is 200 feet above the Bolan river, all building and other materials were conveyed to the sites of works on two metre-gauge inclined planes, which were constructed from the broad-gauge branch up to the tunnel entrance. These were on the three-rail system, that is, with the central rail common to both lines, and with passing sidings half-way where the ascending and descending trucks passed each other, so that the steel ropes never crossed the rails. The lower incline was 2,000 feet long, with gradients rising on 1 in 25 ( 4 per cent.), and 1 in 10 (10 per cent.), while the upper incline (which was longer in use than the lower) was 375 feet long, on a gradient of 1 in $2 \frac{1}{2}$ (40 per cent.) throughout. Each incline was worked by its own winding-engine, and the upper incline had two special trucks, so constructed, on wheels of different diameters, that the platforms with their pairs of metre-gauge rails were always horizontal during transit. The material wagons were carried on the tops of these incline-trucks, being shunted on at the bottom and off at the top, and vice versâ. The whole was improvised from various old materials on hand, and worked satisfactorily without accident. There being no water in the Bolan channel at this neighbourhood, the water-supply to this tunnel, as well as to the heavy works for about 4 miles into the Bolan Valley, had to be obtained from some springs near Bibinani, being brought by gravity through a line of $4 \frac{1}{2}$-inch wrought-iron piping, 7 miles long, and distributed, in different directions, through many more miles of branch-piping of smaller diameters.

The country for the $2 \frac{3}{4}$ miles between the Panir and the Seetul Tunnels, leading down into the Bolan Valley, is of the roughest and most difficult description. No conception of its roughness and difficulties could be formed from an inspection of the centre-line section, though that shows a succession of tunnels, deep cuttings, and high embankments (notably No. 29 , which is 95 feet high for about $\frac{1}{8}$ mile, and contains more than $378,000 \mathrm{cubic}$ yards of earthwork), while one gorge is a narrow cleft 100 feet wide by 150 feet deep. The girders (of 150 feet clear span) now spanning this gorge were hoisted from below in pieces, built close to site, and were then run out on wire ropes stretched across the cleft over a derrick, which could be inclined to bring the girders into their positions. This bridge is on a curve of 1,433 feet radius $\left(4^{\circ}\right)$. The general inclinations of the hill-sides range between 1 to 1 and 3 to 1 ; and it was along "goat-paths" cut on them that the bricks and cement, and other materials, had to be carried to the works on 
donkeys; while the wheelbarrows, metre-gauge trucks, and timber had to be carried on men's backs, along places where a false step meant falling to depths of 100 feet or 200 feet.

The strata of these hills are chiefly nummulitic limestone; but in places there are layers of red and green clays lying at steep inclinations under the rock, which gave much trouble both in the tunnels and cuttings, requiring the former to be heavily timbered and fully lined, and breast-walls to sustain the slopes of the latter. The principal works on this length are:-

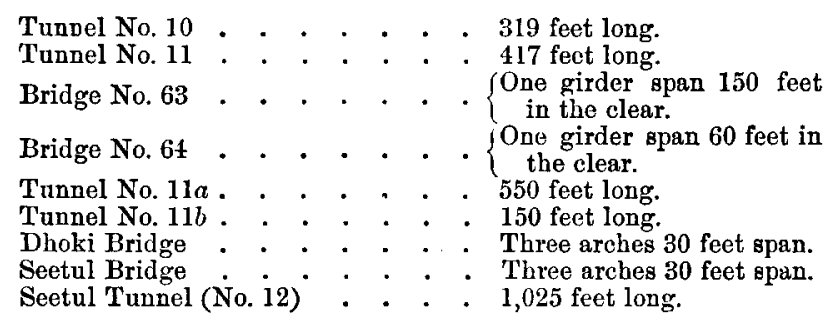

The Seetul Tunnel (1,406 feet above sea-level), through limestone conglomerate, is $30 \frac{\mathrm{l}}{2}$ miles from Sibi, and from here to Ab-i-gum station $(2,157$ feet above sea-level $), 39 \frac{1}{2}$ iniles from Sibi, the railway winds along the slopes of the hills skirting the eastern edge of the stony Lalachi Plain, on an almost continuous embankment. The bridges are exceptionally numerous, and nearly every one of them required different treatment in regard to details of design, as well as in regard to the special training-works necessary to suit the localities, and induce the floods to use them. Close observation can alone qualify for successful construction in these hilly countries, as the application of any formulas to determine the waterways required in them, even when the rainfall is known, is delusive. Many of the training-works extend for long distances from the bridges, and are of solid masonry walling, or a combination of masonry and concrete walling, the numerous retainingwalls being of similar construction. Experience in the re-construction of the Sind-Pishin Railway (Harnai route) showed that only solid masonry, deep founded, can resist the scouring force of the floods. The talus across which the new railway runs is very steep in places, and the floods move enormous masses of gravel and boulders, which, if checked by narrow outlets, would simply pile up against the obstacles and bury or overwhelm them by sheer weight of material. All openings of and under 20 feet span have deep dropwalls built from abutment to abutment, both up and down stream, with flooring between (laid in mortar) 4 or more feet below the 
natural level of stream-beds, at inclinations varying between 1 in 5 and 1 in 10, according to the locality; and it is expected these precautions will prevent back-scouring from the down-stream sides. Between Chidderzee and $\mathrm{Ab}$-i-gum stations, $3 \frac{1}{4}$ miles, the railway turns across the Lalachi Plain, over so many ill-defined watercourses that a long viaduct of twenty girder spans 60 feet in the clear, and numerous smaller openings aggregating some 500 lineal feet of waterway, are not considered too much to ensure its safety. The Pishi station is 31 miles, and the Chidderzee station 36 miles, from Sibi, their respective heights above sea-level being 1,458 feet, and 1,865 feet. About 1 mile from Pishi and $1 \frac{1}{2}$ mile from Chidderzee stations, are some small springs whose waters are collected into sumps, for supplying the stations by gravity through wroughtiron pipes; and, as a temporary arrangement, the water was distributed to the.works by gravity for long distances, the district being a desolation of limestone boulders, and shingle, practically waterless. To the works in the neighbourhood of Ab-i-gum station water was led by gravity, through wrought-iron pipes laid deep across the Bolan channel, from a place nearly 4 miles distant.

Between Sibi and Ab-i-gum the ruling gradient is 1 in 55 (1. 81 per cent.), compensated for curvature, the sharpest curvature being 1,011 feet radius $\left(5^{\circ} 40^{\prime}\right)$, which has only been allowed where flatter curvatures would have increased the cost of the works abnormally. The general rise is continuous, with the exception already mentioned, of the undulation between the Panir and Seetul tunnels, which, however, is unavoidable, owing to the difference of level between the Mushkaf and the Bolan Valleys. Between Ab-i-gum and Mach stations, a length of 7 miles, the ruling gradient is 1 in $33 \cdot \dot{3}$ ( 3 per cent.), compensated for curvature; and as the general slope of this upper part of the Lalachi Plain varies between 1 in $40(2 \cdot 5$ per cent.) and 1 in 25 ( 4 per cent.), a tortuous alignment was obligatory to get so flat a gradient as 1 in $33 \cdot \dot{3}$ ( 3 per cent.). Over this length the railway is on a continuous low embankment with but few culverts, though the plain is furrowed by numerous dry watercourses. Many of these, however, have been judiciously cut into each other, thus concentrating the drainage at the places where provision has been made for passing it. It may be mentioned that the foundations of all embankments are soled, from toe to toe, with layers of boulders, hand-laid, between 15 and 30 inches high, according to their heights and the wealth of their neighbourhoods in boulders. This method facilitates the drainage, by preventing water lodging along the up-stream toes of embankments. 
The site selected for the Mach engine-changing station is on the bare stony plateau overlooking the Bolan, but 100 feet above the torrent bed, and 2 miles down-stream from Old Mach. It is 3,246 feet above sea-level, $46.12 \mathrm{miles}$ from Sibi; and owing to the slope of the ground at the confined space available being 1 in 40 , it is laid out as a "reversing" station, so that the rear ends of trains entering it become the leading ends when leaving it. By this arrangement ample siding accommodation is enabled to be provided, on the level, for both traffic and locomotive purposes, and more compactly than could be done at this place by any other. ${ }^{1}$ The special engines for working trains over the steep gradients will be stationed here, and there have been built a large station and offices, a commodious engine-shed complete in all requirements, numerous houses for the employees, as well as a large masonry tank capable of holding 120,000 gallons, the water being led into it by gravity, through wrought-iron piping, from springs opposite Old Mach, about $2 \frac{1}{2}$ miles up the valley.

The "Upper Bolan" extends from Mach to Kolpur, a length of $15 \frac{1}{2}$ miles, the vertical rise being 2,628 feet, almost $\frac{1}{2}$ mile. The ruling gradient is 1 in 25 ( 4 per cent.), of which there are! 12 miles practically continuous out of the $15 \frac{1}{2}$ miles. The 8 miles from Mach to Hirok (4,652 feet above sea-level, and $54 \frac{1}{2}$ miles from Sibi) are over an open shingle beach 60 feet to 80 feet above the Bolan torrent, on light works, except for the mile in the Mach gap, where there are some large cuttings through very compact limestone conglomerate, and a bridge, 65 feet high, across the Hannar Nulla just above its junction with the Bolan. The piers of this bridge, spaced at 160 feet centres, are of very massive stone masonry, and, to deflect the furious Bolan floods past the bridge, extensive protective walling has been built in the neighbourhood of both abutments, with, in addition, a high, specially strong masonry groyne near the north abutment. The principal works on this 8-mile length are:-

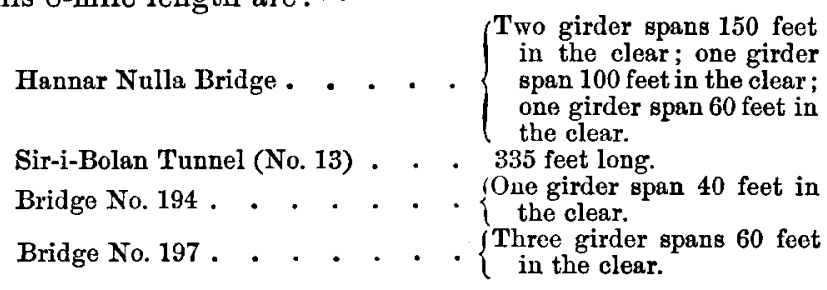

1 It has been found convenient to carry the line straight through Mach without using the "reversing" station. 
The general slope of the Bolan torrent-bed between Mach and Hirok is 1 in 25, and the old Bolan Railway was originally laid along it; but, this being one of the localities most liable to severe damage by floods, the permanent way was taken up and laid on the new formation in the summer of 1892 , and connected with the old railway from the dip in front of the Hannar Nulla Bridge by a temporary "zigzag" on 1 in 25 ( 4 per cent.) gradients, the vertical rise being 160 feet in about $\frac{1}{2}$ mile. By these means the length of temporary line subject to flood damage in this neighbourhood was reduced to about 1 mile, and the transport of material was satisfactorily worked over the "zigzag" until the Hannar Nulla Bridge was completed. It should be mentioned that the old Bolan Railway between the upper end of the Kundilani Gorge and Mach was closed in the summer of 1893 , when the materials were lifted and laid on a temporary alignment parallel to the permanent works from Panir to Mach, so that, except between Sibi and the upper end of the Kundilani Gorge, there was nothing left of the old Bolan Railway, which, however, had proved useful, if not indispensable, to the new works.

Hirok, noted for its bleakness, is situated on a bare wind-swept boulder slope, and from it to the summit at Kolpur $(5,874$ feet above sea-level, and 62 miles from Sibi), a length of $7 \frac{1}{2}$ miles, the works are exceptionally heavy, being a succession of deep cuttings, tunnels, high embankments (often supported by massive retaining walls), and large bridges in diverse styles of construction. The defile in the Dozan Gorge, about 6 miles long, is so narrow and tortuous, and so confined between high vertical cliffs, that the new railway is forced to cross and re-cross it nine times in 4 miles, the bridge design for each crossing having to be specially considered to suit it to the varied conditions of site. The general slope of the torrent-bed in the gorge is between 1 in 20 and 1 in 23, becoming flatter, however, towards the upper end. The new formation throughout is high above the floods, being, in fact, mostly 20 feet above the old so-called "high-level" line. The bridges are built with massive limestone masonry in Portland cement mortar; and, where piers in the torrent-bed are unavoidable, they have been constructed parallel to the axis of the torrent, the cutwaters of some being like those on Canadian railways for parting ice floes. Many of these bridges cross at very acute angles, and some are on reverse curves. The principal works on the $7 \frac{1}{2}$ miles between Hirok and the summit at Kolpur station are:- 
Dherok Nulla Bridge (No. 204) . . $\left\{\begin{array}{c}\text { Four girder spans } 60 \text { feet } \\ \text { in the clear. }\end{array}\right.$

jOne girder span 150 feet

* Pir Panjah Bridge (No. 210) . . $\left\{\begin{array}{l}\text { in the clear, three spans } \\ \text { of } 30 \text {-foot arches. }\end{array}\right.$

Tunnel No. 13a . . . . 200 feet long.

Cascade Bridge (No. 211) . . . $\left\{\begin{array}{c}\text { Three girder spans } 60 \text { feet } \\ \text { in the clear. }\end{array}\right.$

Cascade Tunnel (No. 14) . . . . 542 feet loug.

* Elgin Bridge (No. 213) . . . $\left\{\begin{array}{l}\text { One girder span } 150 \text { feet } \\ \text { on the }\end{array}\right.$ in the clear; four arches
of 30 feet spen. Two girder spans 100 feet

* Bridge No. 214 . . . . . $\left\{\begin{array}{l}\text { in the clear, and two } \\ \text { girder spans } 40 \text { feet in } \\ \text { the clear. }\end{array}\right.$

* Bridge No. 214 . . . . . $\left\{\begin{array}{l}\text { in the clear, and two } \\ \text { girder spans } 40 \text { feet in } \\ \text { the clear. }\end{array}\right.$

* Bridge No. 214 . . . . . $\left\{\begin{array}{l}\text { in the clear, and two } \\ \text { girder spans } 40 \text { feet in } \\ \text { the clear. }\end{array}\right.$ * Bridge No. 215 . . . . $\left\{\begin{array}{l}\text { Two girder spans } 100 \text { feet } \\ \text { in the clear, and one } \\ \text { girder span } 60 \text { feet in the } \\ \text { clear. }\end{array}\right.$ *Crux Bridge (No. 216) . . . . $\left\{\begin{array}{c}\text { Four girder spans } 60 \text { feet } \\ \text { in the clear. }\end{array}\right.$ Windy Corner Tunnel (No. 15) . . 406 feet long.

* Dozan Bridge (No. 221) . . . . $\left\{\begin{array}{c}\text { Two girder spans } 100 \text { feet } \\ \text { in the clear. }\end{array}\right.$ (Two girder spans 150 feet * Bridge No. 233 . . . . . . $\left\{\begin{array}{l}\text { in the clear, one girder } \\ \text { in }\end{array}\right.$ Mary Jane Tunnel (No. 16) . . . 581 feet long.

* Bridge No. 236 . . . . . . $\left\{\begin{array}{c}\text { Four girder spans } 60 \text { feet } \\ \text { in the clear. }\end{array}\right.$ Sangani Bridge (No. 241). . . $\quad\left\{\begin{array}{c}\text { Five girder spans } 40 \text { feet } \\ \text { in the clear. }\end{array}\right.$

* Ninth and Last Bolan Bridge fSeven girder spans 40 feet (No. 243). . . . . . . $\{$ in the clear.

Bridge No. 246 . . . . . . $\left\{\begin{array}{c}\text { Two girder spans } 40 \text { feet } \\ \text { in the clear. }\end{array}\right.$

Bridge No.250... . . . $\left\{\begin{array}{c}\text { Four girder spans } 40 \text { feet } \\ \text { in the clear. }\end{array}\right.$

Summit Tunnel (No, 16a) . . 315 feet long.

The bridges marked * are over the Bolan torrent, and five of them, viz., Nos. $210,213,214,215$, and 216, occur on the same mile, No. 214 being on a curve of 900 feet radius $\left(6^{\circ} 25^{\prime}\right)$, the sharpest curvature on the railway, and No. 216 on a curve of 955 feet $\left(6^{\circ}\right)$ radius. Tunnel No. 14 is through a cliff of hard, blue limestone, and some light Ingersoll machine-drills were used in driving the top headings. Tunnel No. 15 is on the 955 feet curve, being the only curved tunnel in the Upper Bolan. It is through a spur of brecciated limestone, which proved very dangerous to work in, and required to be very heavily timbered under the supervision of English miners. As the declivities of the small side ravines range between 1 in 3 and 
1 in 10, the arching, where arched culverts are built, is in steps at inclinations of 1 in 20. The new works extend for about $1 \frac{1}{2}$ mile beyond Kolpur, which is an engine-changing station, provided with convenient siding accommodation, an engine-shed, turntable, \&c., as the special locomotives for working over the steep gradients will stop here, and trains will be worked to and from Quetta $(5,500$ feet above sea-level), 25 miles distant, by ordinary locomotives, the ruling gradient being 1 in 100 ( 1 per cent.). The Dozan station $\left(5,161\right.$ feet above sea-level) is on a level " back-shunt" $57 \frac{1}{4}$ miles from Sibi, and about half-way between Hirok and Kolpur. Water is brought to this station in wrought-iron pipes from some springs about 2 miles away among the hills, going by gravity to Hirok, and is pumped up to Kolpur station, where a tank of 100,000 gallons capacity has been built.

This being a military railway, on which, in the event of war, the safety of the army may depend, it seemed to the Author essential that the four-wheeled rolling-stock with 16-foot wheelbase from all the broad-gauge railways in India should be able to use it with safety, and he endeavoured to make the limiting radius of curvature $1,011 \cdot 5$ feet $\left(5^{\circ} 40^{\prime}\right)$, and even to use this as seldom as possible; but in the Dozan Gorge, so exceptionally narrow and tortuous, one curve of 900 feet radius $\left(6^{\circ} 22^{\prime}\right)$, and another of 955 feet radius $\left(6^{\circ}\right)$, already mentioned, are unavoidable for safe work. With guard-rails laid along them, they will prove no hindrance to the passage of the long wheel-base four-wheeled rolling-stock from all India. The most frequent curvature on the railway is of 1,433 feet radius $\left(4^{\circ}\right)$. Owing to the curves of 600 feet to 800 feet radii $\left(9^{\circ} 33^{\prime}\right.$ and $\left.7^{\circ} 10^{\prime}\right)$ scattered over the whole length of the undulating Sind-Pishin Railway (Harnai route) on its nominal 1 in $40(2 \cdot 5$ per cent.) gradients, considerable transhipping is necessary at Sibi, from four-wheeled wagons with 16-foot wheel-base into the bogie-wagons which are mostly used on the frontier railways. It has been found that the curve resistance of a train composed of bogie-wagons is greater than that offered by a train composed of four-wheeled wagons.

The ruling gradients on the new railway are:- 1 in $55(1 \cdot \dot{8} \dot{1}$ per cent.) from Sibi to Ab-i-gum, $39 \frac{1}{2}$ miles; 1 in $33 \cdot \dot{3}$ ( 3 per cent.) from $A b$-i-gum to Mach, 7 miles; and 1 in 25 (4 per cent.) from Mach to Kolpur, $15 \frac{1}{2}$ miles, and on all curves the ruling gradients have been "compensated" or flattened, the compensation adopted being 0.05 per degree (central angle) of curvature, so that the ruling gradients are actual and not nominal. The very steep gradients have been "bunched" on the $22 \frac{1}{2}$ miles length between Ab-i-gum 
and Kolpur, for convenience of working with auxiliary engines, and vertical curves have been introduced to ease all important changes of gradient. Five catch-sidings, with gradients rising to 1 in 5 (20 per cent.), have been made on this length, mostly just above the stations, to stop runaway trains, and be checks on the speeds of all descending trains. As their points will always be locked for the catch-sidings, each descending train must stop dead before they are opened for its passage onwards. All the stations have been made defensible, with their walls loopholed for musketry, and the water-towers form part of the buildings. There are in all thirteen stations, and they are built at convenient distances apart to facilitate working the traffic of a single line; but some of them, notably Bohr Hill, Sir-i-Bolan, and Dozan, will probably be converted into mere "signal-stations" for their catch-sidings, after a double line is laid. Each station has two 8-inch diameter watercolumns between the lines.

In the Mushkaf Valley all the masonry is of brickwork in Portland-cement mortar. Twenty-nine millions of bricks were manufactured near Sibi, where kilns were built immediately after sanction was received to start the new railway works; but, the supply of coal-dust from the local coal-mines near Khost, on the Sind-Pishin Railway, proved inadequate, and the moulders, who were all specially imported from the Punjab, being difficult to keep, 11 millions had to be manufactured at and transported from Jacobabad, where there is abundance of wood-fuel and labour. All bricks were required to be burned specially hard, to withstand the action of the magnesian and other salts with which the soil is impregnated. The masonry in the Bolan Valley is built with stone in Portland-cement mortar, excepting the arching, which is all of brickwork. The ratio of sand to cement is between 4 to 1 and 6 to 1 , and in some instances 7 of sand was used to 1 of cement. The concrete, both in foundations and in retaining walls, was composed of 1 cement, 4 sand, and 6 of shingle and broken stone (in equal parts), with large rubble-stones placed at intervals throughout the work. All the Portland-cement was imported from England, and 194,244 barrels were used. About 45 miles of wroughtiron piping, of diameters between $4 \frac{1}{2}$ inches and $1 \frac{1}{2}$ inches, were in use for supplying and distributing water, by gravity, to these works. The explosives used were dynamite, gelignite, nitroglycerine, and European and native blasting powders. A temporary manufactory for the latter was established near Mach, at which considerable quantities were produced. About 80 tons of dynamite were used on the works. 
The tunnels and their entrance cuttings are all made for the double line; and, wherever it was possible to utilize the material in them, the opportunity was taken to make other cuttings to the double line width also. The widths of the tunnels are between $29 \frac{1}{2}$ feet on the straight, and $\mathbf{3 3}$ feet according to the radius of the curve on which each occurs. Most of them are, however, on the straight.

The girders for the bridges are of steel, and are designed to carry specially heavy engines. The roadway is on the top booms, with corrugated plates for supporting the ballast and permanent way, the line being laid on ballast throughout. The weight of the girder-work is 7,438 tons. The ballast is gravel and small shingle throughout. From Sibi to $\mathrm{Ab}$-i-gum it is 18 inches, and from Ab-i-gum to Kolpur 21 inches deep. As far as Ab-i-gum the permanent way is that previously used on the old Bolan Railway, being partly double-headed steel rails, $75 \mathrm{lbs}$. per yard, on DenhamOlpherts cast-iron sleepers, Figs.4, Plate 7; and flat-footed steel rails, 75 lbs. per yard, on steel transverse trough sleepers, of the ordinary State Railway pattern. Although the Denham-Olpherts seems a fragile style of cast-iron sleeper, or plate, it stood well among the shingle and boulders in the Bolan, until battered by the stones during floods. From Ab-i-gum to the summit at Kolpur, flatfooted steel rails are used, weighing $100 \mathrm{lbs}$. per yard, on steel transverse trough sleepers with corrugated or buttressed lugs, Figs. 3 and 5. The sleepers are 8 feet 9 inches long, and weigh $135 \mathrm{lbs}$. each; and each is fitted with a steel key and with a distance-piece, weighing together 3 lbs., Figs. 6, Plate 7. The steel transverse trough sleeper seems admirably suited for these frontier railways, so long as it is not laid in the moist soils heavily impregnated with salts, where nothing seems to last except castiron and wood. With the steel trough sleeper and the DenhamOlpherts systems, "creep" is unknown on the Sind-Pishin and Bolan Railways. For the "catch-sidings" the old iron and other obsolete rails from the old Bolan Railway will be used.

The locomotives for working the material trains on the lower lengths were the ordinary $L$ class, with six wheels coupled, weighing 46 tons exclusive of tender; but for the steep gradients four of the special locomotives supplied, in 1888, to the Khojak Tunnel works were used. ${ }^{1}$ These are specially-designed eightwheel coupled tank-engines (with the tank over the boiler), the coupling-rods being joined together with ball-and-socket joints to increase their flexibility on curves. The capacity of the tanks

1 Minutes of Proceedings Inst. C.E., vol. cxii. p. 311. 
and coal-bunkers was afterwards increased, so that each engine now weighs over 63 tons, and the ordinary loads were 100 tons on the 1 in 25 ( 4 per cent.) gradients. The fuel was a mixture of local and English coal, except on the steep gradients, where only English coal was used. Special engines are being made for this railway, each of which is to take 170 tons, in addition to its own weight, at 8 miles an hour up the 1 in 25 (4 per cent.) gradients; and 250 tons at 10 miles an hour up the 1 in 33 ( 3 per cent.) gradients.

The lowlands of this district are literally the hottest part of the earth's surface, the thermometer often registering $124^{\circ} \mathrm{F}$. in the shade. In the winter the upper passes are filled with snow, and the temperature falls to $18^{\circ}$ below zero, rendering out-door labour impossible. The new railway rises 5,440 feet in a length of about 55 miles; or 660 feet lower than the Sind-Pishin Railway (Harnai route) on an undulating length of about 100 miles. Both summits are, however, higher than those on European mountain railways, the Semmering being 2,500 feet, the St. Gothard 3,800 feet, the Mont Cenis 4,200 feet, and the Brenner 4,400 feet above sea-level; while the Mushkaf-Bolan height is 5,874 feet and the Sind-Pishin height is 6,534 feet.

Owing to the low fluctuating values of the rupee during recent years, and to special circumstances pertaining to this railway, no proper comparison can be made between its cost and that of mountain railways in other countries. It may be stated, however, that the estimated cost of the earthworks, including rock cuttings, is Rs.31,73,579, or Rs.54,018 per mile; tunnels, Rs.34,66,604, being at the rate of Rs.357 per lineal foot; large bridges (of 40-foot spans and over), including girders, complete, Rs.59,45,543, or Rs.1,01,200 per mile; small bridges (of 20-foot spans and under), including girders, complete, Rs.23,53,906, or Rs.40,066 per mile; the total of the estimates sanctioned for the new works, $58 \cdot 75$ miles long, being Rs.2,00,85,470, or at the rate of Rs.3,38,088 per mile, complete.

Under the rules of the Indian Public Works Department, the Author retired in July, 1894; and, since then, this railway has been completed by his successor, Mr. C. W. Hodson, M. Inst. C.E., with a saving on the original estimates. Unfortunately, the financial straits of the Government of India did not allow of sufficient funds being annually provided for so active a prosecution of the works as was expected when they were sanctioned, which added considerably to their cost, gave them a bad reputation in the eyes of people seeking work, and delayed their completion by 
eighteen months. The work was all done under the "petty contract" system. The petty contractors were natives of India and Afghanistan, many of the latter being unable to either read or write. The unskilled labourers were from Afghanistan, Hazara and the Punjab. Pathans make excellent "navvies," using their picks, shovels, drills and wheelbarrows "as if to the manner born," and find this kind of work more profitable than picking up a precarious existence by raiding and robbery. All skilled labour, such as that of masons, carpenters and other artisans, was imported from the Punjab and Kurrachee at high rates of pay, as the Bolan has a bad name for sickness and expensive living. Besides the crowds of different animals carrying bricks, stones, cement, \&c., to the masonry works, great numbers of donkeys, mules, camels and other pack-cattle were employed carrying earth to the high embankments, their passage from and to the borrow-pits having the effect of consolidating-punning in fact-the loose soil. There were also many miles of tramways in use, of 18-inch, 24-inch, 30-inch, and metre-gauges. From the temporary foundry, which was erected at Hirok shortly after these works were started, the output was between 5 tons and 7 tons a month; consisting of tramway wagon-wheels, bearings, brake-blocks, barrow-wheels and numerous other articles; the scrap mostly used being the broken Denham-Olpherts sleepers with which the Bolan torrent was strewn. The cost of working this foundry was amply repaid, as, besides saving the heavy railway freight from Kurrachee, everything was made more cheaply and of superior workmanship. Dispensaries and hospitals, with the necessary medical staff, were established in the neighbourhoods of the heaviest work on the different districts; and such very stringent sanitation was enforced throughout that there was no epidemic of sickness.

In selecting the alignment, care was taken to avoid running unnecessarily into engineering difficulties, but such difficulties as were unavoidable were boldly met; and, the Author believes, this new railway will give a safe and stable line of communication between the plains and the Baluchistan Plateau, after such unforeseen minor weak points have been rectified as are sure to develop on the heavy works of this mountain railway, through so wild and difficult a country. Successful maintenance of such railways can only be ensured by attending to the first signs of danger, and by skilful promptness in initiating repairs; while the policy of niggardly vacillation, or economical weakness, and strict adherence to routine, induces expensive and, not infrequently, ruinous disasters.

The old Bolan Railway, viâ the Kundilani Gorge, has now 
entirely disappeared, and the materials been used on the new railway. It has been stated that the narrow Dozan Gorge is probably unique, in that traces of two abandoned railways and a wrecked military road can still be seen in it. A train was run through from Sibi to Quetta, over the new railway, ${ }^{1}$ in five hours, the distance being $87 \frac{3}{4}$ miles; and the Government have ordered the "bunched" steep-gradients, from $\mathrm{Ab}$-i-gum to Kolpur station (the summit), to be laid with a double line.

The following Table shows the distances of various points on the line from Kurrachee, the seaport:-

\begin{tabular}{|c|c|c|c|c|c|c|c|}
\hline & & & & & & $\begin{array}{c}\text { Distance } \\
\text { from } \\
\text { Kurrachee. }\end{array}$ & Remarks. \\
\hline $\begin{array}{l}\text { Ruk Junction : } \\
\text { Sibi. } \cdot \text { : } \\
\text { Mach : } \\
\text { Kolpur } \cdot \text { : } \\
\text { Quetta : } \\
\text { Bostan Junction } \\
\text { Khojak Tunnei } \\
\text { Chaman : - }\end{array}$ & $\dot{\bullet} \cdot$ & & $\begin{array}{l}\dot{:} \\
: \\
: \\
: \\
: \\
: \\
.\end{array}$ & $\begin{array}{l}: \\
: \\
: \\
: \\
: \\
:\end{array}$ & $\begin{array}{l}: \\
\dot{.} \\
\dot{.} \\
\dot{.} \\
\dot{.}\end{array}$ & $\begin{array}{l}\text { Miles. } \\
\mathbf{3 1 8} \\
451 \frac{1}{2} \\
498 \\
513 \\
\mathbf{5 3 9 \frac { 1 } { 4 }} \\
\mathbf{5 5 9} \\
\mathbf{5 8 5 \frac { 1 } { 2 }} \\
605 \\
627\end{array}$ & $\begin{array}{l}\text { Mushkaf-Bolan summit. } \\
\text { Mushkaf-Bolan route. } \\
\text { Harnai } \\
6,398 \text { feet above sea-level. } \\
\left\{\begin{array}{c}\text { Nearest military post to Kandahar, } \\
4,505 \text { feet above sea-level. }\end{array}\right.\end{array}$ \\
\hline
\end{tabular}

Between Chaman and Kandahar, a distance of some 75 miles, the country being easy and undulating, the rails can be very quickly laid when required.

The district engineers were Mr. W. A. Johns, Assoc. M. Inst. C.E., in the Mushkaf Valley; Mr. C. J. Cole, Assoc. M. Inst. C.E., at the Panir Tunnel and the Lower Bolan; and Mr. T. E. Curry, M. Inst. C.E., in the Upper Bolan. The engineers on these frontier railways, in addition to their engineer duties, have to perform those of contractors' agents, and commissariat officers, as all food supplies, \&c., for the work-people have to be imported from distant markets, no supplies of any kind being obtainable in the districts traversed.

The Paper is accompanied by two tracings from which Figs. 1 to 6, Plate 7, have been prepared.

!. The Times, 1 October, 1895. 


\section{A P P E N D I X.}

Particulars and Costs of the Tunnels.

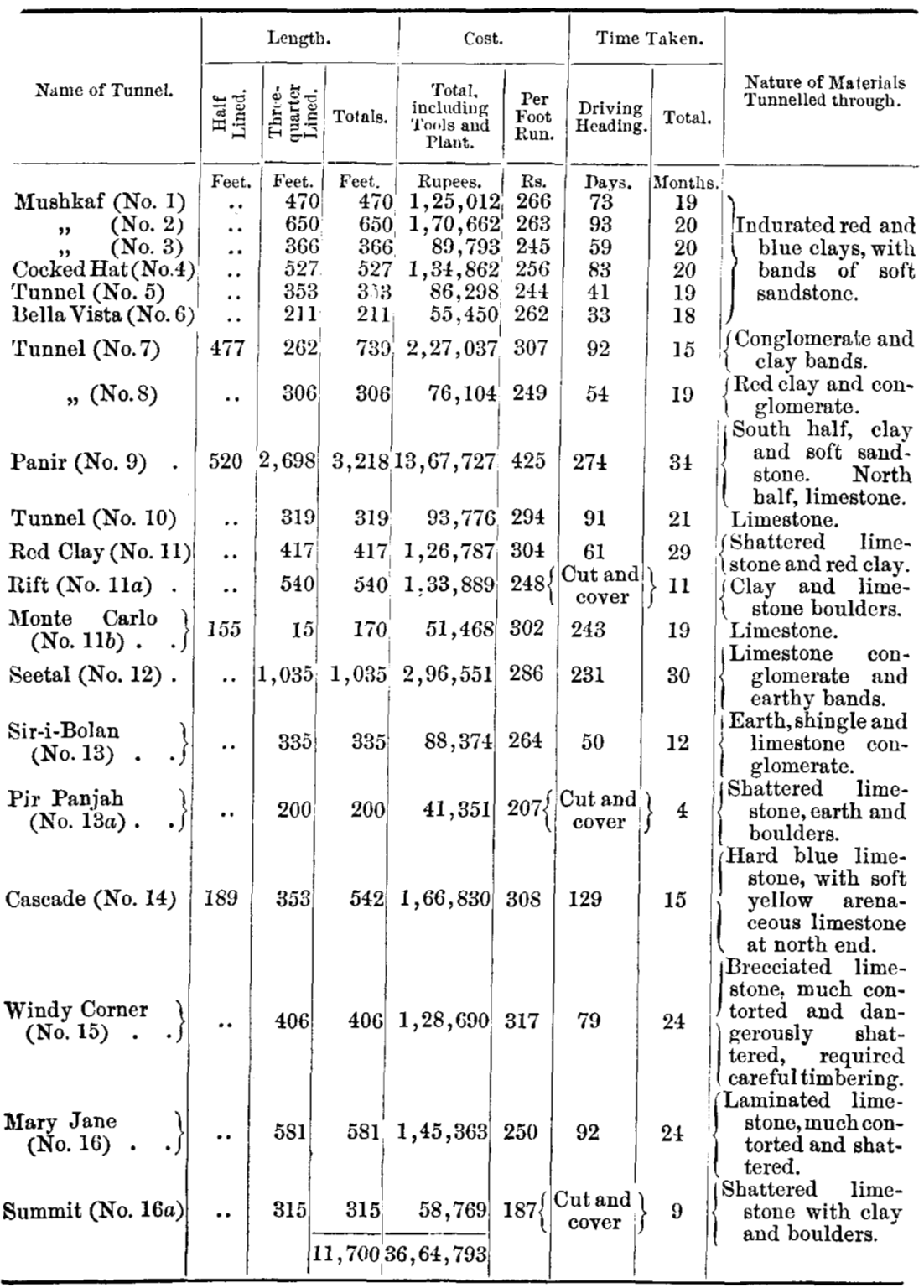


